\title{
The Challenges of Microentrepreneurship Tourism as a New Tourism Destination in Surabaya
}

\author{
Dian Yulie Reindrawati a 1 iD \\ ${ }^{a}$ Universitas Airlangga, Surabaya, Indonesia
}

\section{APA Citation:}

Reindrawati, D.Y. (2020). The challenges of microentrepreneurship tourism as a new tourism destination in Surabaya. TIJAB (The International Journal of Applied Business), 4(2), 116-124.

Submission Date: 16/09/2020

Acceptance Date: $11 / 11 / 2020$

\begin{abstract}
This research is conducted due to the existence of new tourism destinations in Surabaya, such as Taman Cahaya, Taman Harmoni and Mangrove Gunung Anyar. The existence of the tourism destinations above gives positive impacts on the community to participate in providing the tourism industry through tourism microentrepreneurship. The objective of this research is to explore the challenges from microentrepreneurship in running the business as a new tourism destination. The method used in this research is qualitative research method with descriptive approach. According to the research results, it is concluded that a new tourism is able to create new opportunities to the community to start a new business with the ideas that the development of tourism will result to more visitors and more money spent by them in the tourism destination. This shows that tourism sector is able to increase the opportunities in starting and developing their own business. The challenges in running microentrepreneurship in tourism areas are influenced by various factors, such as lack of awareness in learning and developing the knowledge with regards to the current business and the business products have not been partnering with online transportation companies in their products development. In Mangrove area, the management of the business vendors seems not well-managed as it can be seen from the absence of food corner and stalls, instead, street vendors are dominating the area. This issue is caused by the lack of financial as well as service supports both from the government and private sectors. The tourism development is considered as the best solution in the tourism area in order to accommodate the tourist needs. As a result, more tourists will visit the area and it will enable the community around the area to increase their economic level. The supports from government and private sectors are also needed to educate microentrepreneurship in developing and promote their products widely.
\end{abstract}

Keywords: challenges, tourism, microentrepreneurship

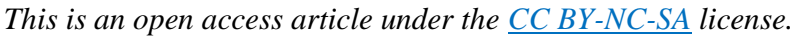

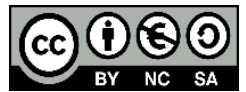

\section{Introduction}

Tourism is one of the main sectors contributing the income in Indonesia right after oils/gas, palm oils and latex (Ministry of Tourism and Economy Creative of the Republic of Indonesia 2012). The

\footnotetext{
1 Corresponding author.

E-mail address: dian.reindrawati@ vokasi.unair.ac.id
} 
advancement of tourism sector is reflected from the increased number of the tourists. The head of the Tourism and Culture office of Surabaya, Antiek Sugiarti stated that the number of tourists visited Surabaya in 2019 alone reached 24 million. This number is beyond the expected target which was targeted to be only 21 million (Liputan6.com).

The high number of visitation to Surabaya is a part of the efforts from the Department of Tourism Surabaya that opens new tourism destination in the city. There have been 9 new destinations in Surabaya, they are The Monument of De Javasche Bank, Hutan Kota Pakal, Taman Cahaya, Kenjeran Park, Patung Budha Empat Wajah, Pagoda Tian Ti, Taman Harmoni and Mangrove Gunung Anyar Surabaya (Department of Tourism Surabaya, 2020)

The existence of new tourism destinations in a region is known to contribute to the growth of tourism microentrepreneurship (Ayeljevic and Doorne, 2000). Microentrepreneurship is a new concept of entrepreneurship. Tourism entrepreneurship refers to the micro tourism entrepreneurs where they are trigerred by non-economy motive and they prefer "staying within the fence" (Ateljevic dan Doorne, 2000 , p. 378) instead of pursuing the uncontrolled economy sector. Peters and Shuckert (2014) found that "these individuals may simply intend to strive for some extra income to enhance, and sometimes secure, their livelihoods - they typically avoid suffocating market environments in order to preserve their quality of life and, accordingly, rely mostly on niche markets" (Morais, Wallace, Rodrigues, Espana, \& Wang, 2014).

Due to the definition and phenomenon of the emergence of tourism entrepreneurs in the tourism destinations in Surabaya, this research focuses on exploring the challenges of microentrepreneurs in Taman Cahaya, Taman Harmoni and Mangrove Gunung Anyar as new tourism destinations in Surabaya. The destinations above are chosen as research locations considering the numbers of tourism microentrepreneurship in the destinations. On the other hand, they have a similar characteristic namely as a forest or city park.

The challenge scope to be projected as a research focus can be an event, condition and distraction affecting to the microentreprenuer ability to run their business. The challenges from micro entrepreneurship is important to identify since they will affect to the sustainability and the ability of the microentrepreneur in resolving the long-term challenges.

\section{Literature Review}

The government in developing countries encourage investment on tourism sector because of the assumption that the tourism development will contribute to the economy development (Hall 1995). One of the trends as a result of tourism development is the emergence of microentrepreneurship tourism concept. Carland and Carland (1997) distinguishing the difference between macroentrepreneurship and microentrepreneurship. Macroentrepreneurship is a business creation stimulating new industries and grow as a dominant giant industry. Meanwhile, microentrepreneurship is referred to the creation "business which never grow, which become fixed as landmarks in our towns, cities and comunities" (p.36). Even though microentrepreneurship is very common in the world, the knowledge and research on the characteristic of microentrepreneur itself is limited.

Microentrepreneur is not affiliated to any professional-formal business network or existing traditional business network (KC, Morais, Peterson, Seekamp, \& Smith, 12017). Several research results shows that by organizing an activity on microentrepreneur tourism, a farmer is able to have an alternative income and not depends on the farming income (Peroff, 2015). The alternative business in tourism microentrepreneurship also increases the ability and pride of the women (LaPan, Morais, Wallace, \& Barbieri, 2016). Micro business normally requires five or more employees and tend to operate in informal business environment (Ferreira, Morais, \& Lorsheider, 2015). 
Previous researches record that the challenges in microentrepreneurship are the lack of financial support (Henrique \& Herr, 2008) and reserve cash (Viswanathan, Rosa, \& Ruth, 2010); the lack of managerial skills (Abor \& Quartey, 2010), inadequate consultation service (Robson et al., 2008), deficiencies in technology (Fafchamps, 1994), inadequate support service (Mead \& Liedholm, 1998), ineffective property rights or license protection (Fowler, 2004), limited access to credit (Fafchamps, 1997) and difficult access to market export (Tybout, 2000). Other factors involve the lack of learning and knowledge development (Viswanathan, Sridharan, Gau, \& Ritchie, 2009), social networking (Robson et al., 2008) and infrastructure (DeBerry-Spence, 2010).

\section{Method}

The author uses qualitative-descriptive method in conducting the research. Qualitative method is used to seeing how Taman Cahaya, Taman Harmoni dan Mangrove Gunung Anyar as new tourism destinations contribute on the tourism microentrepreneurship and the challenges on the business. The qualitative-descriptive method is used in this research so that the author is able to understand all the phenomenon related to the issues happening on the tourism microentrepreneurship to explore the challenges.

The final result of this paper is aimed to provide recommendations and suggestions related to the effects on the sustainability and ability of the microentrepreneur in solving the long-term challenges. Qualitative research also provides an opportunity for the author to explore the information and data found in the research locations accurately. All of the data obtained by the author will be directly delivered to reveal in-depth research results. The research locations are at Taman Cahaya, Taman Harmoni and Mangrove Gunung Anyar. The author organized a lesson for three months starting from June to August by visiting the informant several times to collect the data in order to obtain the accurate and accountable information for the validity of the research.

The informants are chosen by using sampling pusposive technique, proceed by an in-depth interview with various informants involved in the series of tourism microentrepreneurship. The author raises the questions directly to the informants on the challenges faced by the microentrepreneurship while running the business at the new tourism destinations. Followings are the list of interviewees:

Table 1 Research informants

\begin{tabular}{|c|c|c|}
\hline No. & Informant & Position \\
\hline 1 & Bagus & Street vendors at Mangrove Gunung Anyar \\
\hline 2 & Inayah & Street vendors at Mangrove Gunung Anyar \\
\hline 3 & Rafi & Street vendors at Taman Harmoni \\
\hline 4 & Budiono & Street vendors at Taman Harmoni \\
\hline 5 & Fatima & Street vendors at Taman Cahaya \\
\hline 6 & Harso & Street vendors at Taman Cahaya \\
\hline
\end{tabular}

The author uses triangulation technique (source) and interactive data guide analysis from the theory on (Miles, Huberman \& Saldaña, 2014), such as: data collection obtained through a series of interviews, documents and transcripts from a recording. The data obtained can be in the form of documents, photographs and interview results with the informant. On the next stage, the author conducts data compression to simplify and clarify the data results in order to assist the readers in understanding the final results easily. The author conducts reduction process in order to clarify that the data gained is related to each other for more accurate explanation. The third stage is data presentation, it is conducted by providing pictures so that the readers will find it easier to understand. Data presentation is a compiled data obtained from the previous research and then through the next process, the compiled data will be 
written into a from that is easy to understand. As a result, to conclude the research, the author concludes the results obtained from the research stage.

\section{Results and Discussion}

Surabaya opens numbers of new tourism destinations such as Taman Cahaya, Taman Harmoni and Mangrove Gunung Anyar. Taman Cahaya is located at Jalan Pakal, situated in the Western Surabaya and the park is as good as the others situated in the heart of the city. Built in a 1,5 hectares area, the park is mostly visited by the local residents for an evening chill or exercising. Taman Cahaya is completed with various facilities such as futsal field, basketball court, jogging track, reflection track, kids' playground, toilets and praying facility.

According to one of the street vendors in the park named Ms. Fatima, Taman Cahaya takes a part in supporting her family with daily needs. Moreover, on holiday season and weekend, she receives double revenues from the sales. On holiday season and weekend, she opens the stalls in the morning up to 09.00 PM. On the weekdays, Ms. Fatima opens the stalls from 04.00-09.00 PM. The park is managed by Spatial Planning office and it operates for public all day. Such opinion also coming from Mr. Harso, one of the street vendors at Taman Cahaya. He admits that Taman Cahaya really supports his family economically and he has not found any challenges when starting his business at Taman Cahaya since the park provides complete facilities for the visitors. As a result, the visitors are able to enjoy the facilities, some visitors even visit the park just to enjoy the sunset. There have been at least two challenges have been found in managing tourism microentrepreneurship, namely lack of learning and knowledge development with regards to the business (Viswanathan, Sridharan, Gau, \& Ritchie, 2009) and the business products have not been partnering with online transportation companies in their products development (Robson et al., 2008). Generally, source of interest in this tourism destination is the natual resources, even though the location itself is a park area.

The stalls management at Taman Cahaya has been well managed as it can be seen from every food corner and street vendor have their own strategic location.

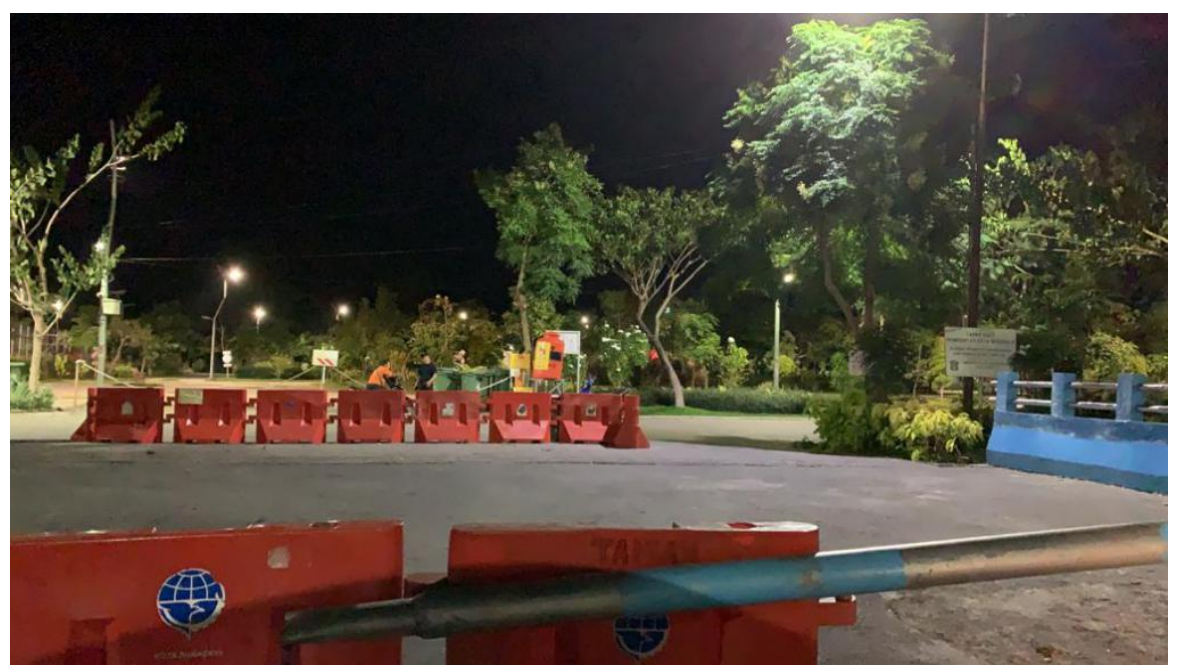

Figure 1. Taman Cahaya

The street vendors at Taman Cahaya consider that the park is looking good and potentially attracting visitors. On the other hand, the sport facilities and playground in the location are considerably the main attractions. Other interesting factor is that most of the street vendors at Taman Cahaya are local residents around Pakal area and it makes a family value among the street vendors are well-bounded. 
The following tourism destination is Taman Harmoni or known as Taman Sakura. This park is located at Keputih Tegal Timur No, 241, Keputih, Sukolilo, Surabaya. Taman Harmon was a landfill in Keputih area until it was finally modified by Ms. Risma into a beautiful park or public attracting the Surabaya citizen and surround it. Taman Harmoni Keputih has a special characteristic from the other parks in Surabaya, namely the existence of Cherry blossoms in the park.

The visitors at Taman Harmoni Keputih Surabaya are normally enjoying a small walk around the park. The beauty of the colorful flowers at the park is a perfect spot for a pre wedding photo session and young people coming for selfies. Other than offering the beautiful and colorful flowers, playground for the children are also available such as slides, seesaw, swings and climbing frames. Toilets facility is provided in the park area and a water fountain completing the beauty of Taman Harmoni Keputih. Reflection track formed through reflection stones is available at some points in the park area. Equipped with such facilities, visitors are attracted to visit the park especially on the holiday season.

Large number of tourists visiting the park is affecting to the increased revenue of tourism microentrepreneurship at Taman Harmoni Tourism Area. There are several factors affecting microentrepreneurship at Taman Harmoni Tourism area. The first factor considered to be the challenge in the development of micreentrepreneurship is the low quality of Human Reourse. The conservative mindset of the community such as littering is affecting the street vendors to run their business outside the park. Such thing is also stated by Mr. Rafi and Mr. Budiono, the treet vendors at Taman Harmoni that such action (allocating the street vendors to run their business outside the park) is taken to control the park cleanliness. The second factor is limited fund affecting the business development, it can be seen from the variety of food and beverages offered by the street vendors that are mostly same.

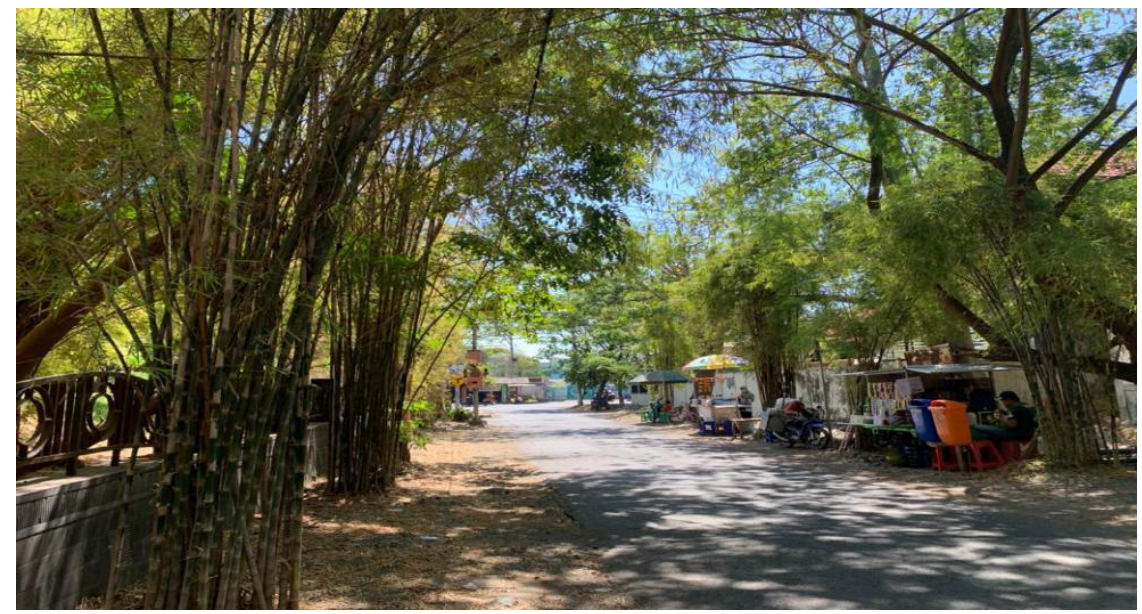

Figure 2. The street vendors at Taman Harmoni tourism area

Mangrove area situated in Eastern Surabaya is a natural conservation area known as Kebun Raya Mangrove. Kebun Raya Mangrove built by the Surabaya City Government is located in 4 different areas, they are Wonorejo, Keputih, Sukolilo and Gunung Anyar. However, Surabaya City Government is still working to develop two areas, they are Gunung Anyar and Wonorejo.

The entrance access from Mangrove Gunung Anyar area looks easy to reach even though some parts of the road have not been paved yet. The visitors can directly park their cars or motorcycle in front of the entrance gate from the jogging track of Mangrove Gunung Anyar. The jogging track is made of Petung bamboo and arranged crossing the mangrove trees area. The twenty meters length of the jogging trach will take the visitors to explore various of mangrove plantation in Mangrove Gunung Anyar area. Some round-shaped spots made of bamboo are provided to the visitors for selfie spots and also for taking 
a rest. Other than selfie spot built from bamboo, praying facility and office management of the park located at the entrance gate of the jogging track are also built from bamboo. At the terrace of the management office, the visitors are welcomed to find various information related to the mangrove plantation in the area. All facilities provided by Kebun Raya Mangrove are free of charge for the visitors visiting the area. Therefore, the infrastructure in the area is considerably sufficient since the road has been paved, supported by the availability of kids' playground and photo spots.

The arrangement of the official merchant in the location does not seem to be well-arranged as it can be seen from the absence of food corner or stalls; instead, street vendors are more dominating the area. This issue is caused by the lack of financial fund (Henrique \& Herr, 2008) as well as inadequate support service (Mead \& Liedholm, 1998) both from government and private sectors.

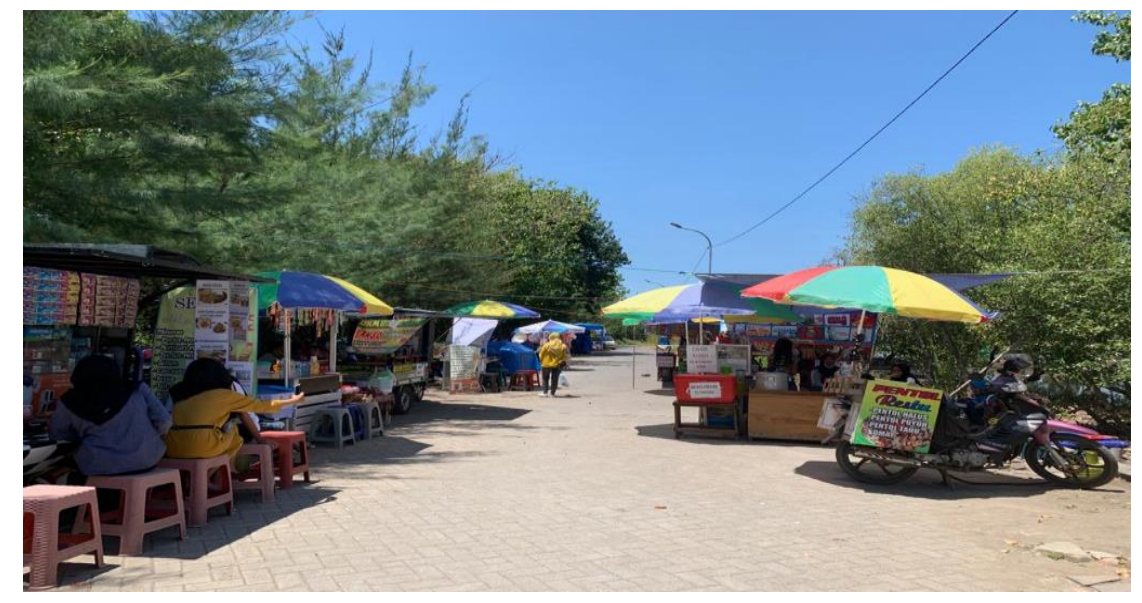

Figure 3. Street vendors at Mangrove Gunung Anyar area

According to Mr. Bagus, the street vendors located in the area are individually organized and not organized under an official association or food corner, permit administrator is the only management system. Kawan Mangrove tourism is likely to positively contribute on the economy sector of the community as most of the street vendors are dominated by the local residents around the area. Since large number of visitors coming during holiday season and weekend, the area operates from 08.00 AM $-04.00 \mathrm{PM}$ and all the street vendors will close their stall operation when it is time to the closing time of the park. Such statement is also stated by Ms. Ina, one of the street vendors there. She claims that Mangrove area has officially been opened since a year ago and Ms. Ina has just been starting her business in the area six months ago. Since lockdown protocol is implemented due to the COVID-19 Pandemic, Mangrove Tourism Area is temporarily closed. That is the challenge in running the business during the pandemic. Especially, the items sold by Ms. Ina is not associated to any social networks (Robson et al., 2008). All street vendors here are managed from the the village of Gunung Anyar under Gunung Anyar Dsitrict. Every Saturday and Sunday, the street vendors are required to pay for garbage management fee in amount of Rp. 10.000, -

The existence of tourism destinations such as Taman Cahaya, Taman Harmoni and Kawasan Mangrove Gunung Anyar is positively affecting to microentrepreneurship supporting the economic income of the surrounding community. This shows that tourism sector is able to stimulate the opportunity for the local residents' economic in the form of tourism microentrepreneurship. The development of the tourism sector will be resulting to the large number of visitors and the local residents starting their business around the area. Generally, the development of tourism microentrepreneurship in Taman Cahaya, Taman Harmoni tourism areas and Kawasan Mangrove Gunung Anyar is considerably good. 
However, the challenges in running the business among the street vendors in the tourism areas have been found as the lack of learning and knowledge development related to the current business, the business products have not been partnering with online transportation companies in their products development. In Mangrove conservation area, the arrangement of the official merchant in the location does not seem to be well-arranged as it can be seen from the absence of food corner or stalls; instead, street vendors are more dominating the area. This issue is caused by the lack of financial fund as well as inadequate support service both from government and private sectors.

\section{Conclusions}

According to the discussion and data analysis on the effects of new tourism towards the challenges in running tourism microentrepreneurship at Taman Cahaya, Taman Harmoni and Kawasan Mangrove Gunung Anyar, it is concluded that tourism development at Taman Cahaya, Taman Harmoni and Kawasan Mangrove Gunung Anyar is well-managed, the increasing on tourism destination is continuously carried out and explored any potentials in order to increase the number of tourists visiting the tourism destinations. Facilities and infrastructures of the tourism destinations are continuously evaluated and improved to create a convenient environment for the visitors, access to the tourism destinations area are now integrated, even though the road is not fully good as it can be seen at Mangrove tourism area. Tourism destinations are more varied and not only limited to the beauty of the nature, but also outdoor sport facilities and extreme sports. Those facilities have also been developed as new attractions and natural tourism destinations are now friendlier for children.

The increased number of tourists is positively contributing for tourism microentrepreneurship, it is proven from the increased revenue in every phase. However, most of the revenue is fluctuating every month depending on the number of tourism visitation. During the COVID-19 pandemic, everything falls down. The increasing indicator of tourism microentrepreneurship in tourism areas showing that tourism sector is able to stimulate economic opportunity of the local communities through microentrepreneurship based on the more develop tourism will be positvely impacting to the large number of tourists and surrounding communities starting a new business due to the tourism potential.

The challenges in running microentrepreneurship in new tourism areas are affected by various factors such as the lack of learning and knowledge development related to the current business, the business products have not been partnering with online transportation companies in their products development. In Mangrove conservation area, The arrangement of the official merchant in the location does not seem to be well-arranged as it can be seen from the absence of food corner or stalls; instead, street vendors are more dominating the area. This issue is caused by the lack of financial fund as well as inadequate support service both from government and private sectors.

\section{References}

Abor, J., \& Quartey, P. (2010). Issues in SME development in Ghana and South Africa. International Research Journal of Finance and Economics, 39, 218-228.

Ateljevic dan Doorne, 2000, Ateljevic, I., \& Doorne, S. (2000). "Staying within the fence": Lifestyle entrepreneurship in tourism. Journal of Sustainable Tourism, 8(5), 378-392.

Dinas Pariwisata Kota Surabaya, (2019), Surabaya Sparkling. Retrieved from https://sparkling.surabaya.go.id/en/ 
Ferreira, B., Morais, D., \& Lorscheider, M. (2015). Using web marketplaces to reach untapped markets. NC Cooperative Extension Publication No. AG-811. Retrieved from http://content.ces.ncsu.edu/using-web-marketplaces-toreach-untapped-markets

Fowler, B. (2004). Preventing counterfeit crafts designs. In M. Finger, \& P. Schuler (Eds.), Poor people's knowledge: Promoting intellectual property in developing countries (pp. 16-19). Oxford: World Bank and Oxford University Press.

Hall, C. M. (1995). Introduction to tourism in Australia: Impacts, planning and development. London: Longman.Carland dan Carland (1997) Carland Jr, J. W., \& Carland, J. C. (1997). Entrepreneurship: An American dream. Journal of Business and Entrepreneurship, 9(1), 33-45

Henrique, M., \& Herr, M. (2008). The informal economy and microfranchising. In S. W.Gibson, \& W. G. Dyer (Eds.), Microfranchising: Creating wealth at the bottom of the pyramid (pp. 43-77). Cheltenham, UK: Edward Elgar Publishing.

KC, B., Morais, D. B., Peterson, M. N., Seekamp, E., \& Smith, J. W. (2017). Social network analysis of wildlife tourism microentrepreneurial network. Tourism and Hospitality Research. doi: 1467358417715679 .

Kementrian Pariwisata dan Ekonomi Kreatif Republik Indonesia. (2012). Ranking devisa pariwisata terhadap komoditas ekspor lainnya tahun 2006-2010 [Devisa rank of tourism 2006-2010]. Retrieved from http://www.budpar.go.id/budpar/asp/detil.asp?c=117\&id=1198BPS, 2019

LaPan, C., Morais, D. B., Wallace, T., \& Barbieri, C. (2016). Women's self-determination in cooperative tourism microenterprises. Tourism Review International, 20(1), 41-55.

Liputan6.com, (2019), 9 Tempat Wisata Baru di Surabaya, Belum Banyak yang Tahu Nih!. Retreived from https://www.idntimes.com/travel/destination/putriana-cahya/9-tempat-wisata-baru-disurabaya-belum-banyak-yang-tahu-nih

Mead, D. M., \& Liedholm, C. (1998). The dynamics of micro and small enterprises in developing countries. World Development, 26(1), 61-74.

Morais, D. B., Wallace, T., Rodrigues, A., España, E. X. A., \& Wang, Y. A. (2014). People-first tourism and the voices of the rural subaltern. Paper presented at the TTRA International Conference: Tourism and New Global Economy, Bruges, Belgium.

Oppermann, M., \& Chon, K. S. (1997). Tourism in developing countries. London: International Thompson Business Press.

Peroff, (2015). The role of tourism microentrepreneurship and agricultural production in shaping stewardship of working lands in Guatemala's highlands and North Carolina's coastal plains. Doctoral dissertation, North Carolina State University, Raleigh, NC, USA.

Peters, M., \& Schuckert, M. (2014). Tourism entrepreneurs' perception of quality of life: An explorative study. Tourism Analysis, 19(6), 731-740.

Robson, P. J. A., Haugh, M., \& Obeng, B. (2008). Entrepreneurship and innovation in Ghana: Enterprising Africa. Small Business Economics, 32(3), 331-350.Fafchamps, 1994

Telfer, D. J., \& Sharpley, R. (2008). Tourism and development in the developing world. Oxon: Routledge.

Viswanathan, M., Rosa, J. A., \& Ruth, J. A. (2010). Exchanges in marketing systems: the case of subsistence consumer-merchants in Chennai, India. Journal of marketing, 74(3), 1-17. 
Viswanathan, M., Sridharan, S., Gau, R., \& Ritchie, R. (2009). Designing marketplace literacy education in resource-constrained contexts: Implications for public policy and marketing. Journal of Public Policy \& Marketing, 28(Spring), 85-94

\title{
Tantangan Tourism Microentrepreneurship Sebagai Destinasi Wisata Baru di Kota Surabaya
}

\begin{abstract}
Abstrak
Penelitian ini dilakukan karena adanya destinasi wisata baru di Surabaya, seperti Taman Cahaya, Taman Harmoni dan Mangrove Gunung Anyar. Keberadaan destinasi pariwisata di atas memberikan dampak positif bagi masyarakat untuk ikut serta menyediakan industri pariwisata melalui wirausaha mikro pariwisata. Tujuan dari penelitian ini adalah untuk mengeksplorasi tantangan dari kewirausahaan mikro dalam menjalankan bisnis sebagai destinasi pariwisata baru. Metode yang digunakan dalam penelitian ini adalah metode penelitian kualitatif dengan pendekatan deskriptif. Berdasarkan hasil penelitian disimpulkan bahwa pariwisata baru mampu menciptakan peluang baru bagi masyarakat untuk memulai usaha baru dengan pemikiran bahwa dengan berkembangnya pariwisata akan menghasilkan lebih banyak pengunjung dan lebih banyak uang yang dikeluarkan oleh mereka di daerah tujuan wisata. Hal ini menunjukkan bahwa sektor pariwisata mampu meningkatkan peluang untuk memulai dan mengembangkan usahanya sendiri. Tantangan dalam menjalankan kewirausahaan mikro di bidang Pariwisata dipengaruhi oleh berbagai faktor, seperti kurangnya kesadaran dalam mempelajari dan mengembangkan pengetahuan tentang bisnis saat ini dan belum bermitra dengan perusahaan transportasi online dalam pengembangan produknya. Di kawasan Mangrove, pengelolaan para pedagang pedagang terlihat tidak terkelola dengan baik karena terlihat dari tidak adanya warung makan dan warung, sebaliknya pedagang kaki lima mendominasi kawasan tersebut. Masalah ini disebabkan oleh kurangnya dukungan finansial dan layanan baik dari pemerintah maupun swasta. Pengembangan pariwisata dinilai sebagai solusi terbaik di kawasan pariwisata guna mengakomodir kebutuhan wisatawan. Alhasil, akan semakin banyak wisatawan yang berkunjung ke kawasan tersebut dan memungkinkan masyarakat sekitar kawasan tersebut dapat meningkatkan tingkat ekonominya. Dukungan pemerintah dan swasta untuk mendidik kewirausahaan mikro dalam mengembangkan dan mempromosikan produknya secara luas.
\end{abstract}

Kata kunci: tantangan, kewirausahaan mikro pariwisata 